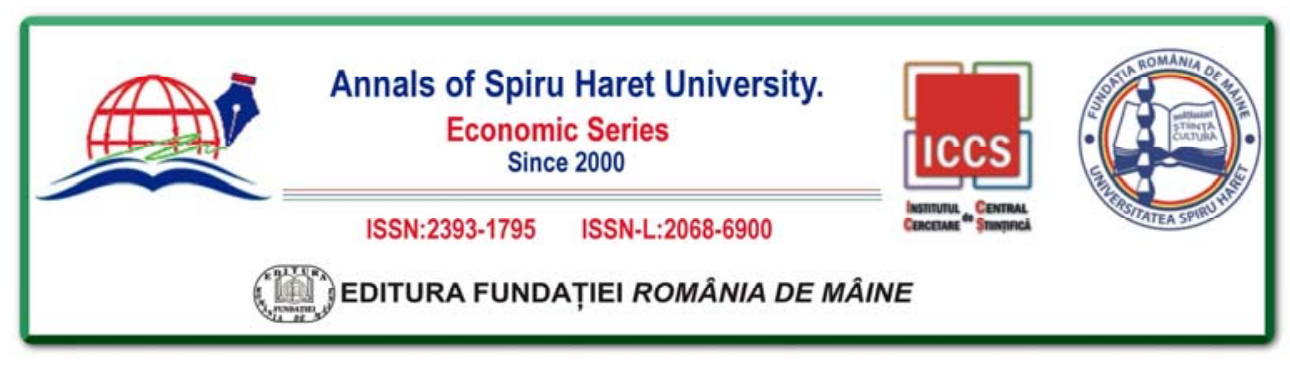

Issue $2 / 2018$

\title{
ICTS AND EMPLOYMENT: NEW OPPORTUNITIES ON THE LABOUR MARKET
}

\author{
Marius SURUGIU ${ }^{1}$, Camelia SURUGIU ${ }^{2}$, Raluca MAZILESCU ${ }^{3}$ \\ ${ }^{1}$ Institute of National Economy, Romanian Academy, Calea 13 \\ Septembrie, Bucharest, Romania, E-mail: mariussurugiu@yahoo.com \\ ${ }^{2}$ Faculty of Administration and Business, University of Bucharest, \\ 4-12 Bd. Regina Elisabeta, Bucharest, Romania, E-mail: \\ cameliasurugiu@gmail.com \\ ${ }^{3}$ Institute of National Economy, Romanian Academy, Calea 13 \\ Septembrie, Bucharest, Romania, E-mail: ralucamazilescu@gmail.com
}

How to cite: SURUGIU, M., SURUGIU, C., MAZILESCU, R. (2018), "ICTs and Employment: New Opportunities on the Labour Market." Annals of Spiru Haret University. Economic Series, 18(2), 117-141. doi: https://doi.org/10.26458/1825

\section{Abstract}

Objectives: In this paper, the potential for increasing employment opportunities and skills availability is investigated. Prior work: E-work activities differ by countries, with impact in various fields. Approach: The statistical data are used to underline the trends. Results: E-work is an emerging process and supports the development of a new business model. Implications and value: From the businesses perspective, $e$-work phenomenon may represent a new opportunity, and competitiveness could be improved. Also, $e$-work may present advantages and disadvantages with influences on the results of workers and businesses. In this paper such trends are analysed, in a comparative approach.

Keywords: information and communication technologies; e-work; eemployment. 


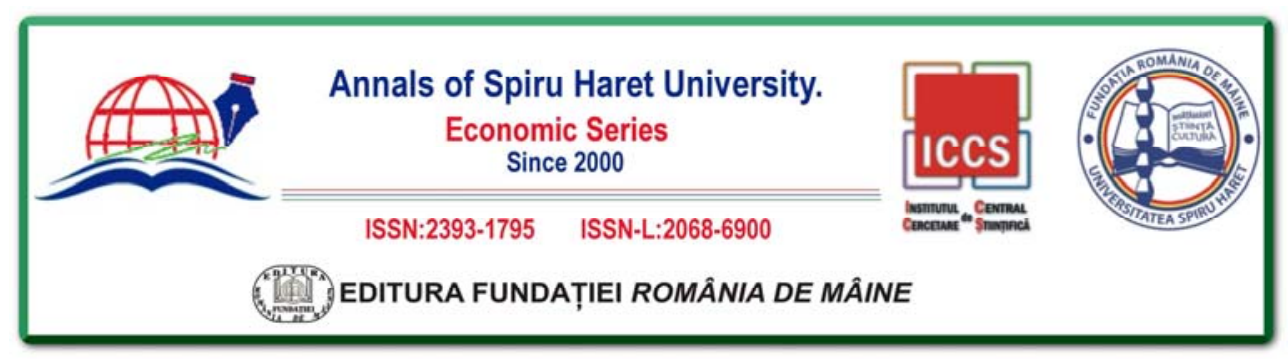

Issue 2/2018

JEL Classification: $\mathrm{E}_{24}, \mathrm{~J}_{21}$

\section{Introduction}

Nowadays, the traditional employment model has evolved and transformed, passing through various shapes and stages. The potential for increasing employment opportunities and skills availability is investigated in this paper. This aspect is important to be analysed, and one important influence came from the growth of online work possibilities that changed the way businesses actually evolve. Thus, businesses may develop teams of qualified employees that work together, no matter of time zone. In this study, the statistical data are used to underline the trends. Also, various aspects of the literature are underlined to support the results of the paper.

Regarding e-work, people searching for jobs are no longer limited to the domestic labour market but are now competitors for the jobs available anywhere on the planet. There are no geographic boundaries anymore and this leads to new growth perspectives for the new employment model in various directions, mainly because those which are interested in a job may choose when to work, where, and so on. Ework refers to activities mainly carried out using ICT and various devices. In the literature we can also find terms such as "teleworking" and "telecommuting".

The term "telework" was first used in early 1970s (a title of a project started in 1973 at the University of Southern California that aimed to study the public policy on the telecommunications - transport trade-off) [ILO, 2016]. Teleworking can take many forms, usually related to the work conducted at home by the workers. Another way to perform job-related activities in a location other than the headquarters of the employer refers to the possibility for workers to meet in satellite offices, remote locations of the headquarter offices, in an area of residence for employees where the access is much easier, reducing travel time, expenses, and so on. Other possibility concerns specific work centres organized by neighbourhood (neighbourhood work centres), with workspaces for employees from different companies, in only one location. A modern method is related to information and communications technologies (ICT) use in any location, turning this into a mobile office, whether an airport, hotel or employee car.

"Teleworking" refers to the use of ICT for solving tasks related to work place in other locations than the office. All types of work assisted by ICT, carried out in a workspace (including work performed at home) are considered as teleworking. An 


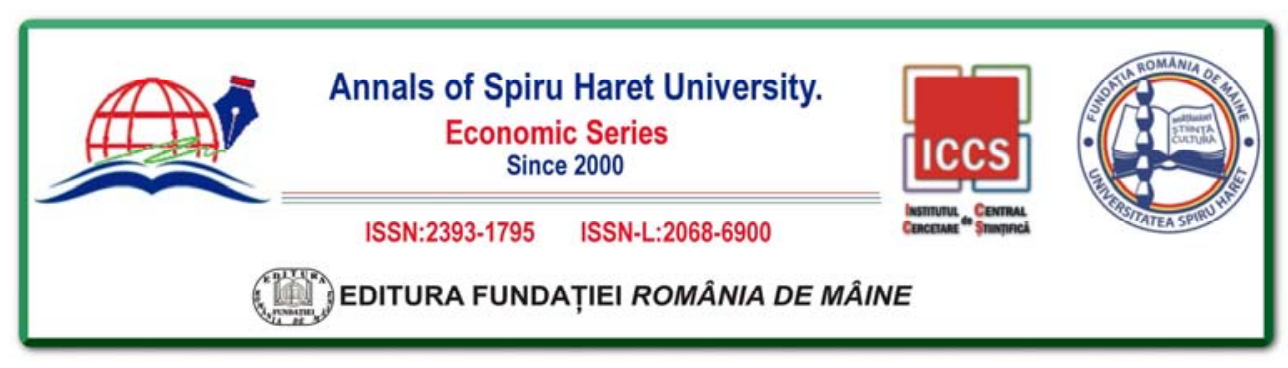

Issue $2 / 2018$

employee can be referred to as a teleworker if she/he has to work with a personal computer (PC), away from the employers' premises, for at least a quarter of the working time [Welz \& Wolf, 2010]. "Telecommuting" concerns the work performed at a particular location, involving the decrease of the period of time required for employees to get to the company's headquarters. That location can be at home or in a place where work-related activities can be performed, but remotely. This can be facilitated by the use of a PC, an Internet connection, a telephone, etc.

For teleworking there are terms like "telecommuting" or "remote work", used to underline the situation where employees of a company are not moving to its premises to carry out activities. Therefore, the person that performs such activities is called "telecommuter", "teleworker" or "home-sourced employee". At the EU level, telework is considered as an expression of the knowledge-based economy and information society [European Commission, 2008].

E-work consists in e-activities, i.e. activities based on and implemented through ICT. These e-activities include e-business, e-commerce, virtual businesses, elearning, e-training, and so on. All these e-activities rely on computer support and communication technologies.

\section{The profile of young graduates' employment}

In various EU countries, youth unemployment rates are particularly high. They form a group with major risks on the labour market. Many young people complete a form of education and start to be implied in activities in the informal sector. The improvement of the educational offer in Romania may positively influence the youth employment on medium and long term [Bălan, 2011].

On the labour market, the selection of employees is made by using criteria such as: knowledge of the specific field, experience, knowledge of foreign languages, communication skills, willingness to accept mobility at work, ability to work under pressure, and so on.

Jobs expectations of young graduates are modified. Many of them are willing to accept a lower wage comparing with the situation from years ago.

The youth employment model is changing, mainly because they want to avoid long-term unemployment that may occur after completion of higher education. Consequently, they may accept part-time or full-time employment, temporary employment or a contract for an indefinite period, but the access to jobs may not be always easy, taking into account that many companies require work experience. 


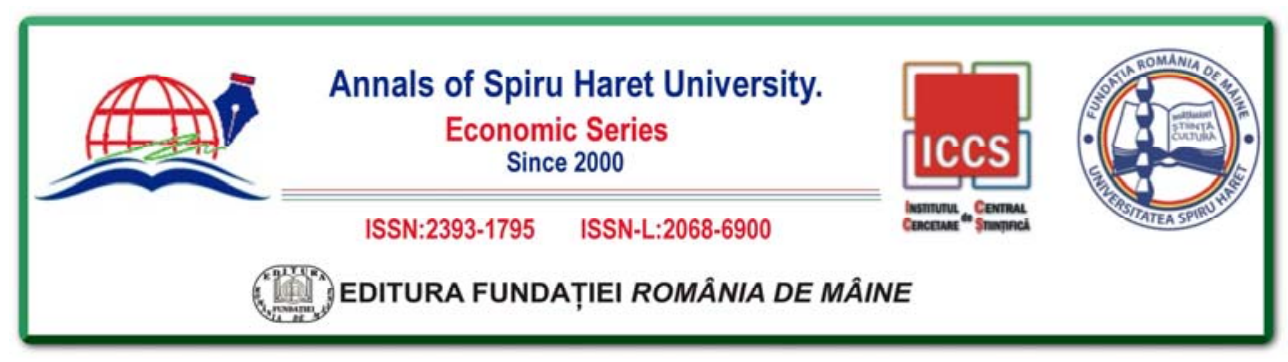

\section{Issue $2 / 2018$}

Thus, young graduates are representing a category at risk on the labour market. The profile of young graduates may be characterized by aspects related to a high level of education, strong attitude towards solving work tasks, desire to develop a professional career, desire to become an employee, prone to mobility at workplace, availability for taking professional development courses, and so on.

They enter the labour market into a direct confrontation with people of different ages and experience that are also looking for a job. However, young graduates have an important advantage in the labour market: they can easily adapt to requirements and conditions set by employers, being very flexible in their decisions. Finding and keeping a job are pressing issues among young people, but they are very creative, have advanced communication skills and can carry various team activities, aspects that underpin the success in identifying a job in an increasingly competitive labour market.

\section{E-work typology}

The connectivity between different types of jobs related to e-work is underlined by the fact that it supports jobs-specific services-workers. They are from the software/hardware sector, social media, etc. Besides these, e-workers are those which use ICT. In their opinion, multiplied jobs have a modern form of management at company level (workers that manage online reports, comparative analysis, etc.), develop a teleworking system and assure networking. Different types of e-work employees are highlighted by the literature. Thus, Bates and Huws (2002) indicated four distinct types, namely: the full time at home e-work employee (or "telehomeworking"); multilocational e-work employee (which usually involves alternating work between working from home and working at the employer's premises); e-lancing worker, a self-employed e-worker offering business services from home based on information; e-enabled self-employed e-worker, an e-worker from home using ICT who does not provide information-based business services. In the opinion of Bates and Huws (2002), the definition of e-work activities is a broad one, including all information processing activities performed away from headquarters, using a computer and a telecommunications network to send the results of work, whether they were made directly by employees or through outsourcing, a distinction being made between e-work activities performed by employees working away from the office (for example, at home) or in multiple locations, and those working remotely, in offices type spaces. 


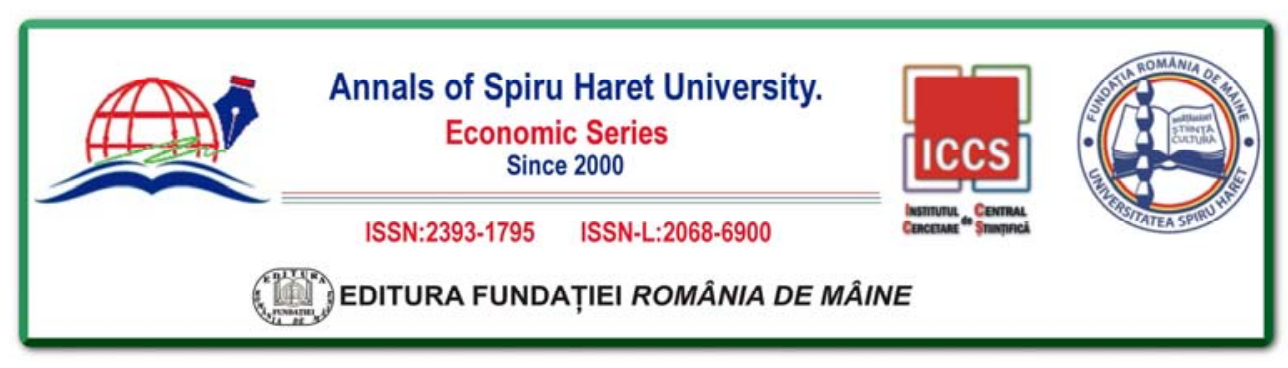

Issue $2 / 2018$

According to OECD (2008), the term "telework" refers to work that is based on ICT and is carried out in a location away from headquarters, meaning other location than the place of production or office, away from peers, employers or clients. The classification of various types of work at distance ("teleworking") is based on characteristics such as the place where work is carried out (at home, while travelling, and so on), the period of time while the activity is conducted away from the office (a week, a month, etc.), and the type of contractual relationship with the employer.

Teleworking represents a work arrangement in which it is not necessary for employees to get to the office to solve job tasks, but e-employment is referring also to workers who solve job tasks in an online environment.

Teleworking may be important for the business strategy of many organizations. Stimulated by the progress occurred in the ICT area, it is the fastest way to get results related to job from home premises. As stated by Eurofound (2012), the terms "telework" or "telecommuting" are related to the use of ICT at job, work being carried out away from employer's premises. The workers who do not work all the time at their employer's or their own business premises and who use ICT are known as electronic nomads or e-nomads (workers who work out of employer's premises and use PC, Internet or email to solve job tasks). The term "e-nomads" refers to workers who use ICT at least sometimes and do not have their employer's premises (or their own premises if self-employed) as their main place of work (or if they do, they have worked in another location at least three months).

As ICT advances, e-work may become a business practice. This may be more than to provide an option for only some employees. Workers' productivity can be improved by minimizing the time spent in the route to the workplace. The most important barriers to the spread of e-work may be the reluctance of companies to use it, and the fact that many jobs are not compatible.

Workers which commit to the goals and objectives of companies - through the relationship employee/employer - are always needed [Messer, 2010]. E-work has many features, often linked to a number of conditions set by the main players on the market and the public decision-maker.

\section{E-work development}

In the literature, there are various discussions related to e-work, in an attempt to highlight the advantages and disadvantages for the employer and the employee. Ework evolves with the development of ICT and knowledge-based economy. 


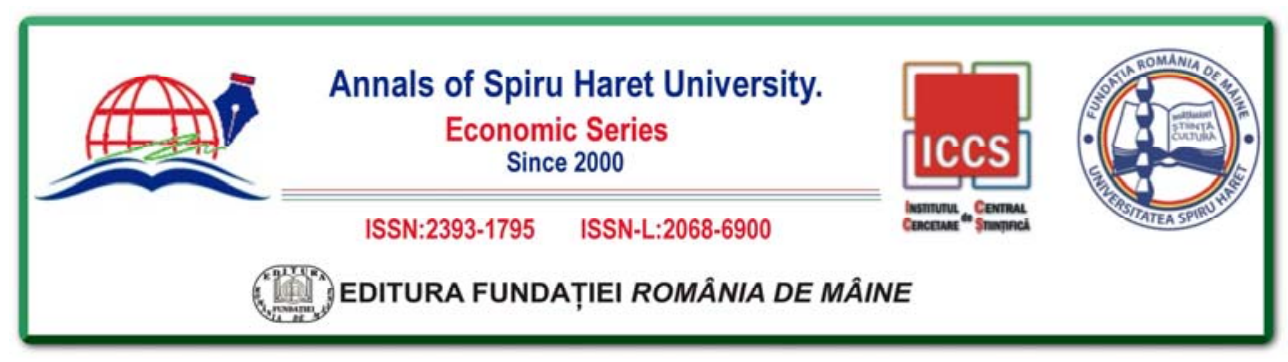

\section{Issue $2 / 2018$}

Some linkages between the benefits of e-work and the effects on the market are highlighted. Flecker and Kirschenhofer (2002) presented a synthesis report of the results from Emergence Study - 2001, with emphasis on employment relocation and e-work, defined as "information-processing work carried out at a distance with extensive use of computer systems and on the basis of telecommunication links". The authors concluded that "relocated e-work offers less stable employment than comparable workplaces". They also stressed the importance of telephone and face-toface meetings, taking into account that "there are considerable limitations to the full replacement of direct communication by electronic information exchange".

Perez et al (2002) analysed the differences between human resource (HR) managers' perceptions of the benefits and barriers to telework adoption. The results indicate that teleworking is seen more feasible where there is a large number of female employees and female HR managers, because they perceive teleworking differently than males HR managers. Women accept more easily the idea that there is some potential of teleworking.

Regarding the extension of e-work on countries and fields of activity, Bates and Huws (2002) discussed about Emergence Project, where a survey was carried out on the situation of some employers from industry, business, financial, and other services, to determine the extent to which employers currently use e-work. According to the survey, there are major differences between countries, both in terms of the extent, and the type of e-work activities performed. The authors pointed out the need for more reliable statistics in EU related to the individualised e-work and the possibility of individualised e-work growth in the EU, taking into consideration the connection with ICT in the case of employers and individuals.

Perez et al (2003) presented the results of a study on the perceptions of HR managers about the feasibility of teleworking in their organizations and discussed aspects such as the percentage of suitable tasks for teleworking, employees involvement in the tasks design, the percentage of salespeople in the workforce, the combined use of teleworking locations, the use of ICT, the company's innovativeness, aspects which positively influence the HR manager's perception of teleworking adoption. Perez et al (2004) analysed the environmental impacts of teleworking, the variables that may influence the use of telework in urban areas, the variables that may influence the link between teleworking adoption and environmental impact (such as geographical dispersion, advanced services, gender, and logistic supplier strategy), and developed a model to evaluate the monetary value 


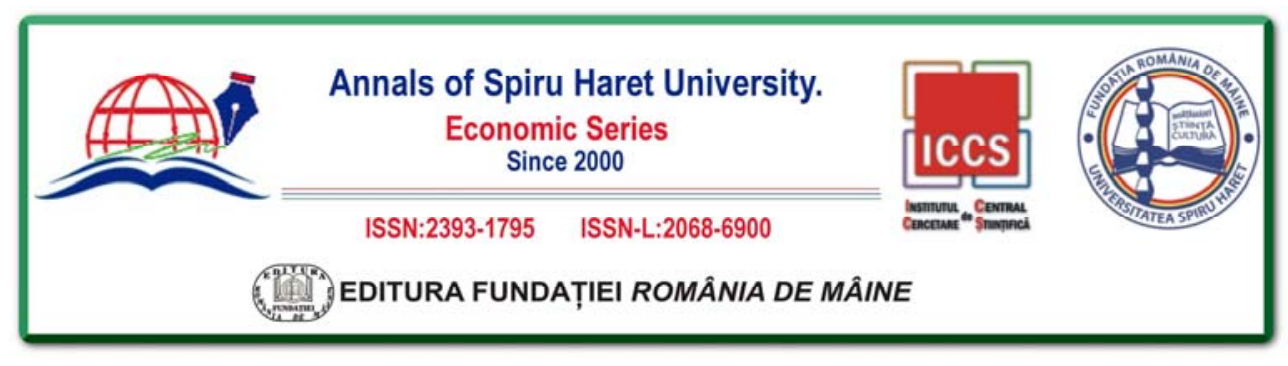

Issue $2 / 2018$

of the environmental impacts of teleworking, underlying that the largest benefit is related to reduction in traffic congestion. Perez et al (2004b) developed a model for the adoption of telework, based on the principles of technology acceptance model, and pointed out that there are three categories of influencing factors: technology, human resources, and organizational factors. The model may be used to identify organisations that are interested in implementing teleworking, and factors such as an innovative culture that fosters change are supporting its adoption. Perez et al (2005) investigated the differences between companies that adopt teleworking and those which do not adopt it. According to the results, the companies from the area of teleworking adopted multiple devices, and the differences are significant for all information equipment types, except for PC. There is a positive correlation between the number of equipment and company size.

Regarding the situation from the European countries, in 2000, the share of employees involved in telework was about $5.3 \%$ in EU15, and $4.2 \%$ in candidate countries. In 2005, the share rose to 7\% for the EU27 area. Many of the countries with a high incidence of telework have had higher growth rates in 2000-2005. The percentage of remote workers rose almost fivefold in the Czech Republic and more than twice in Belgium, Denmark and Latvia. A downward trend in the use of telework was evident in five countries - Bulgaria, Cyprus, Luxembourg, Portugal and Romania, while the share in the UK seemed to stagnate at a level above the average [Welz \& Wolf, 2010]. There have been more than 9 million e-workers in Europe in 2000, with the largest group of multilocational e-workers, estimated to 3.7 million persons, which includes employees who work partly at home and partly at work place and those who work in "nomad" mode or at customers' premises [Bates \& Huws, 2002].

In 2002, teleworking share was different depending on the country (\% of total workforce) [OECD, 2008]. In EU10, Finland was on first place for the situation of a regular teleworker (which works at least 1 day/week) with $10.8 \%$ of total workforce, followed by Netherlands $(8.3 \%)$ and Sweden $(8.0 \%)$. The lowest value was in 2002 in Ireland, of $1.9 \%$, and the EU10 average was $4.1 \%$. For EU, the category "occasional teleworker" (which works less than 1 day/week) is considered with highest values for Sweden (7.2\%), Netherlands (6.3\%), and Finland (6.0\%), while the lowest values were registered for Spain $(0.8 \%)$, Italy $(0.7 \%)$, and France $(0.6 \%)$, with the EU10 average of $2.0 \%$.

In 2004, within EU15, the percentage of employees who used Internet for finding information and who worked outside the company headquarters in the last 


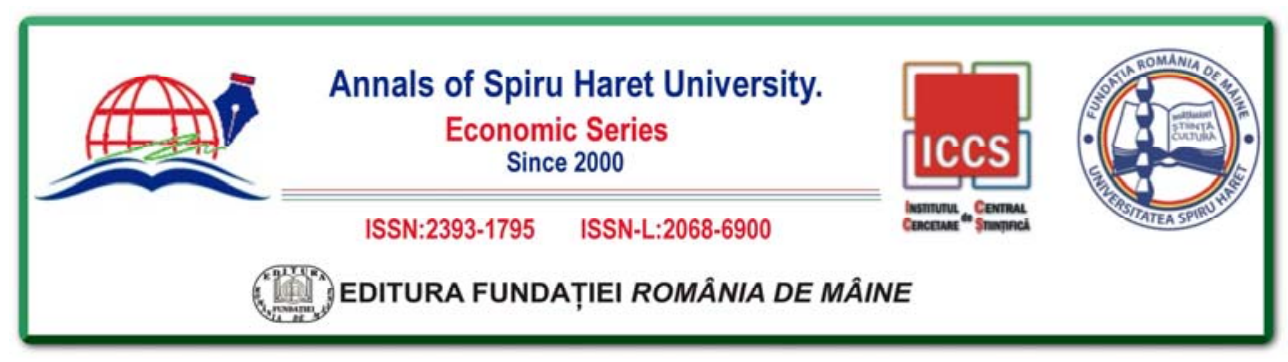

\section{Issue $2 / 2018$}

three months was the highest in Germany and Luxemburg (about 42\%), and the lowest share was recorded by Lithuania (about 12\%). In the case of Internet usage for communication, the country ranked on first position was Germany (about $31 \%$ ), and the lowest value was for Latvia (about $10 \%$ ).

According to Eurofound (2005), in EU27, the highest percentage of employees involved in teleworking was in the Czech Republic, where $15.2 \%$ of employees practiced teleworking for "at least a quarter of the working time or more", followed by Denmark (14.4\%) and Belgium (13\%). Romania had a per cent of $2.5 \%$ of people engaged in teleworking. Bulgaria had the lowest percentage, with only $1.6 \%$ of workers which use telework "at least a quarter of the working time or more". Regarding the category "\% of persons engaged in teleworking almost all working time", on the first three positions were the Czech Republic (9\%), Slovakia (3.4\%), and Austria (3.2\%). Romania had a per cent of about $0.7 \%$. The lowest value was found in Sweden and Portugal (0.4\%).

The category of e-nomads in EU27 (\%) registered the higher percentage in financial services sector (nearly 50\%) and the lowest in wholesale, retail, food and accommodation sector (about 15\%). Regarding occupations, "managers" represented the category with highest percentage (nearly $50 \%$ ), followed by "professionals" (slightly above $45 \%$ ), with the lowest percentage for elementary occupations (about $5 \%$ ). About $25 \%$ of European workers were in the category of e-nomads, with shares varying by country: Bulgaria, Romania (just above 5\%), Netherlands, Denmark, Sweden (about 40\%), and Finland (45\%). Also, e-nomads were mostly men (65\%), with tertiary education (55.5\%), with age between $35-49$ years old (45\%) [Eurofound, 2012].

The situation of teleworking in some EU countries had the following evolution [Arsov, 2008; Ciutacu, 2008; Coletto, 2008; Díaz, 2008; Hárs \& Neumann, 2008; Eurofound, 2012; Jean, 2012]:

- EU - in 2003, the proportion of teleworkers amounted to an average of $13 \%$ in the EU15, while in the new Member States that joined the EU in 2004, the average share of teleworkers was $5.4 \%$; only $18 \%$ of workers were teleworkers in 2012, when financial services, other services, education, and public administration and defence were the sectors with the higher incidence of e-nomads; in 2012, on average, e-nomads worked longer hours.

- France - only 9\% of workers were teleworkers in 2012; the government adopted a development plan for teleworking; European framework agreement on 


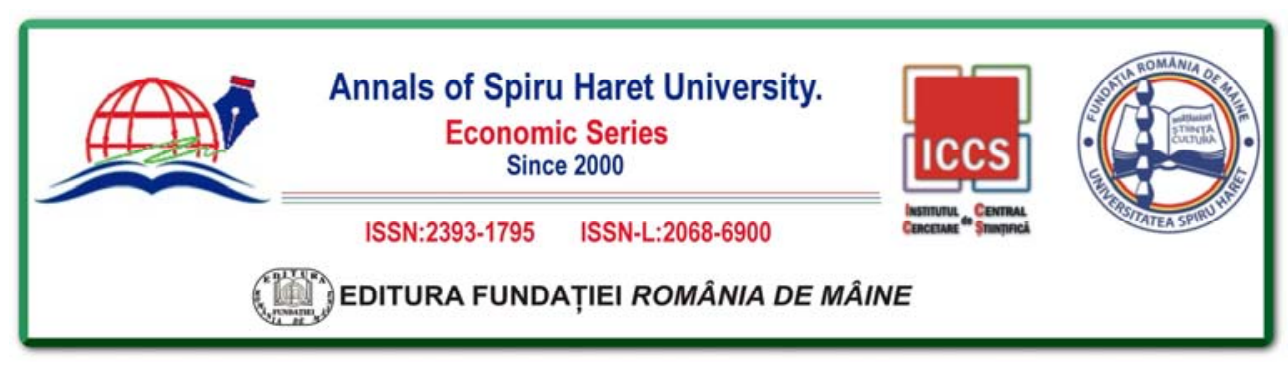

Issue $2 / 2018$

telework was included in the French law in 2005; the possibility for public servants to work remotely was included in legislation in 2012.

- Italy - a national agreement which transposed the European framework agreement on telework was signed in 2004; the spread of teleworking in 2006 was higher in the following sectors: post and telecommunications $(24.6 \%$ of all companies in the sector have developed one or more forms of teleworking), chemical products (14.4\% of chemical companies have used some form of teleworking) and wholesale and retail trade $(8.4 \%$ of all companies have implemented one or more practices on telework); in 2005, in the public sector, the number of remote workers has risen to 470 persons - the equivalent of $0.1 \%$ of the total employees in this sector; of the 470 teleworkers from public administration, 314 were women and the majority - 365 workers - have worked for local authorities; in 2006, 31.2\% of companies with more than 250 employees have developed one or more forms of telework, while only $2.9 \%$ of businesses with 10-49 employees have applied practices on telework.

- Spain - there was a royal decree governing such type of employment in the public sector; the number of teleworkers was among the lowest in the EU15 before EU enlargement in 2004 and 2007, above Portugal (3.4\%) and below France $(6.3 \%)$; in most companies, teleworking was not covered by collective bargaining.

- Hungary - in 2004, the estimated number of teleworkers was 36,000 persons, $60 \%$ men and $40 \%$ women; in the same year, teleworkers represented $2 \%$ of the total employed population, or $2.1 \%$ among male and $1.8 \%$ among female; $20 \%$ of teleworkers were senior officials and managers, compared with $7 \%$ of the total employed population, and $32 \%$ of teleworkers were professionals, compared with $13 \%$ of the total employed population; some $10 \%$ of teleworkers were clerks; more than half of teleworkers were in the services sector, and $13 \%$ of them in manufacturing; among the different service sectors, the most important were: real estate and various business service activities (19\% of all teleworkers), trade (11\%), education $(10 \%)$, and public administration $(9.5 \%)$.

- Bulgaria - in 2003, teleworkers represented 5.5\% of the total workforce; at the beginning of 2006 , between $70 \%$ and $82 \%$ of companies had access to the Internet, and about $30 \%$ of employed persons could use the Internet at work; only $2 \%$ of Internet users were online all the time; the highest share $(11 \%)$ used it on a more casual basis (less than 8 hours/week). 


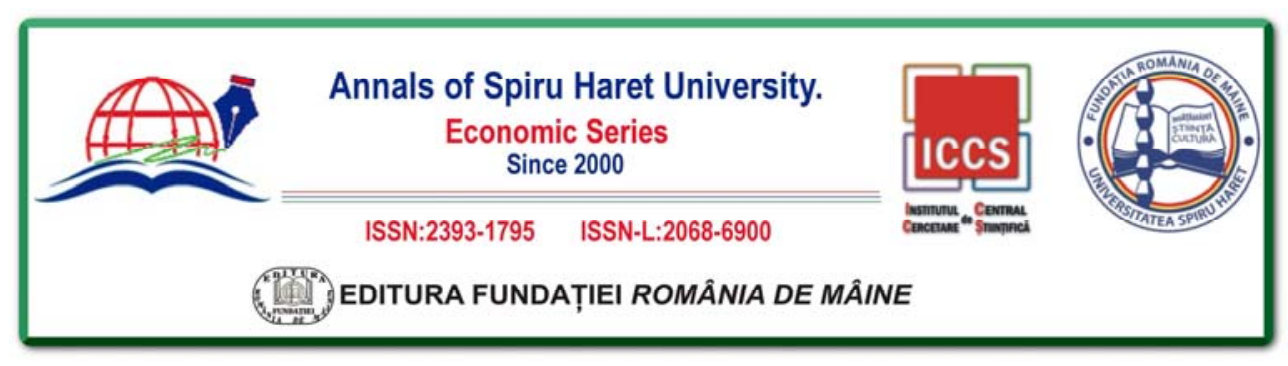

\section{Issue $2 / 2018$}

- Romania - the potential number of remote workers ranged between 16,500 and 56,000 people in 2000; these figures increased to 33,400 and 90,300 teleworkers in 2005 , when people working at home represented $13.7 \%$ of total employment; the distribution by age group of people working at home was as follows: 16.4\% (15-24 years), $8.8 \%$ (25-49 years) and $25.8 \%$ of workers with 50 years and above 50 years; the share of e-workers was estimated at $0.5 \%-1 \%$ of the labour force in 2008 .

Table no. 1. The distribution of the answers to the question: "Does your work involve working with computers, laptops, smartphones, etc.?” (\%)

\begin{tabular}{|c|c|c|c|}
\hline Sector & $\begin{array}{c}\text { (Almost) all of the } \\
\text { time }\end{array}$ & (Almost) never & $\begin{array}{c}\text { Between } 1 / 4 \text { and } 3 / 4 \text { of } \\
\text { the time }\end{array}$ \\
\hline \multicolumn{4}{|c|}{ Public administration, education and health } \\
\hline European Union & 32 & 30 & 37 \\
\hline Romania & 25 & 35 & 40 \\
\hline \multicolumn{4}{|c|}{ Financial and other services } \\
\hline European Union & 50 & 34 & 17 \\
\hline Romania & 31 & 55 & 15 \\
\hline \multicolumn{4}{|c|}{ Construction and transport } \\
\hline European Union & 19 & 61 & 20 \\
\hline Romania & 15 & 62 & 23 \\
\hline \multicolumn{4}{|c|}{ Commerce and hospitality } \\
\hline European Union & 25 & 48 & 27 \\
\hline Romania & 30 & 49 & 20 \\
\hline \multicolumn{4}{|c|}{ Agriculture and industry } \\
\hline European Union & 23 & 55 & 22 \\
\hline Romania & 12 & 75 & 13 \\
\hline
\end{tabular}

Source: Eurofound, 2015.

In Romania, in 2013, of the total employed population of 9,247 thousand persons, 3,473 thousand persons were users of ICT, and only 632 thousand persons were working remotely, using ICT. Most users of ICT within the developed activities were males from urban areas. A small percentage of employed men and women were working remotely using ICT [INS, 2014]. 


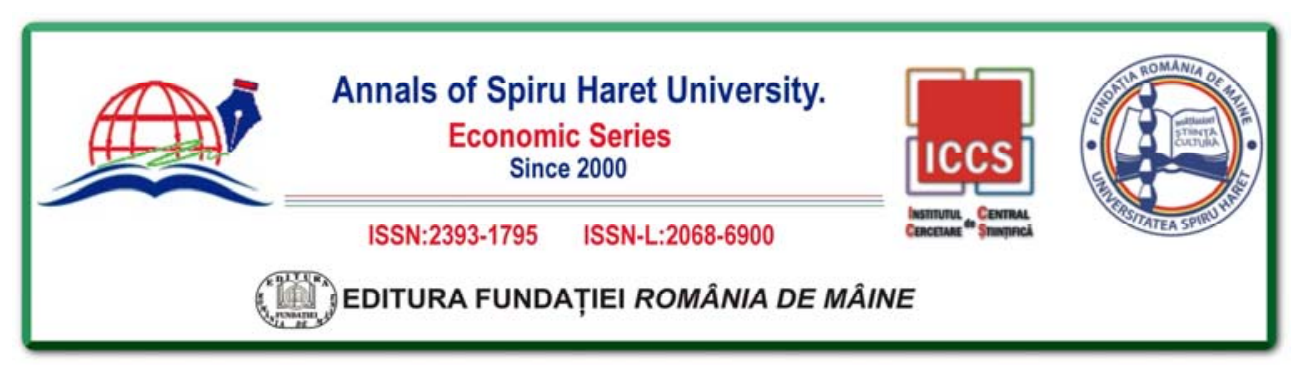

Issue $2 / 2018$

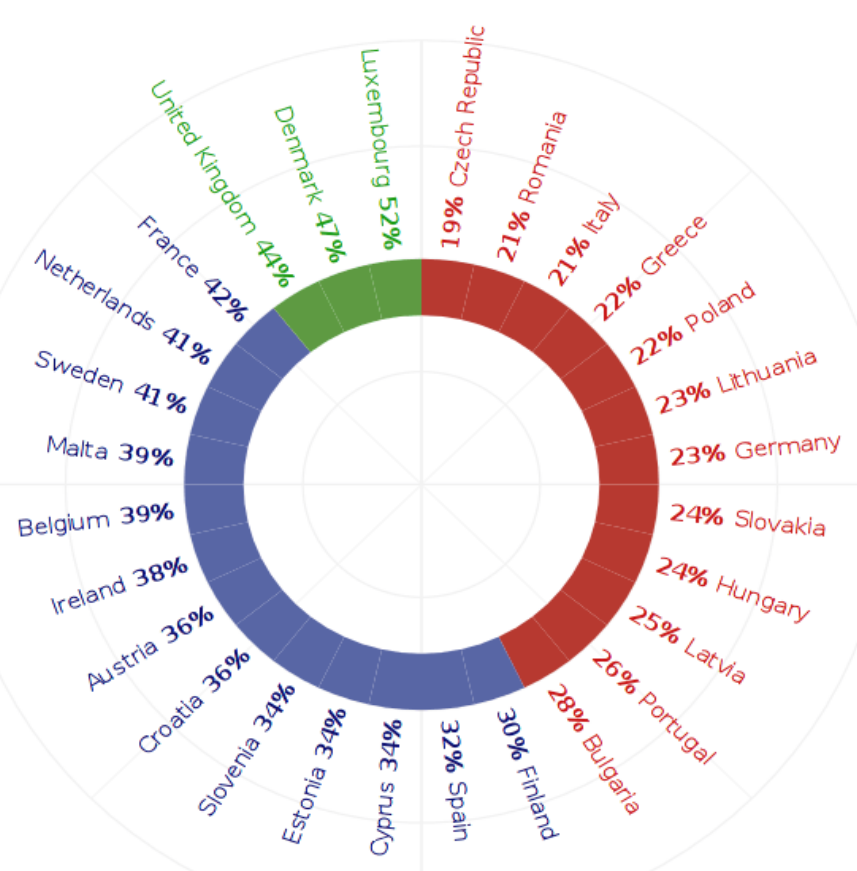

Figure no. 1. The share of respondents that declared they used IT devices (almost) all of the time, by country, \%

Source: Eurofound, 2015.

The spread of digital technologies contributed to the growth of the share of workers that declared in 2015 that they used ICT at work with a high intensity ( $a$ high intensity means using ICT at least $3 / 4$ of all time). The increase was from $21 \%$ in 2005 , to $26 \%$ in 2010 and to $37 \%$ in 2015 . At the same time, within the same period, the proportion of those indicating a medium use of ICT at work increased from $15 \%$ to $20 \%$, but the share of persons that worked with a low intensity of ICT recorded a significant shrinkage of 21 p.p., from $64 \%$ in 2005, to $43 \%$ in 2015 [Eurofound, 2017]. 


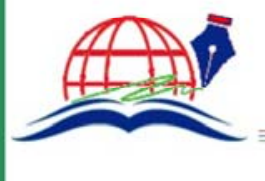

Annals of Spiru Haret University.

Since 2000

ISSN:2393-1795 ISSN-L:2068-6900
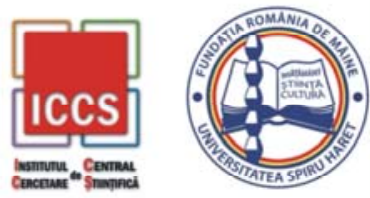

\section{EDITITRA FUNDAṬIEI ROMÂNIA DE MÂINE}

Issue 2/2018

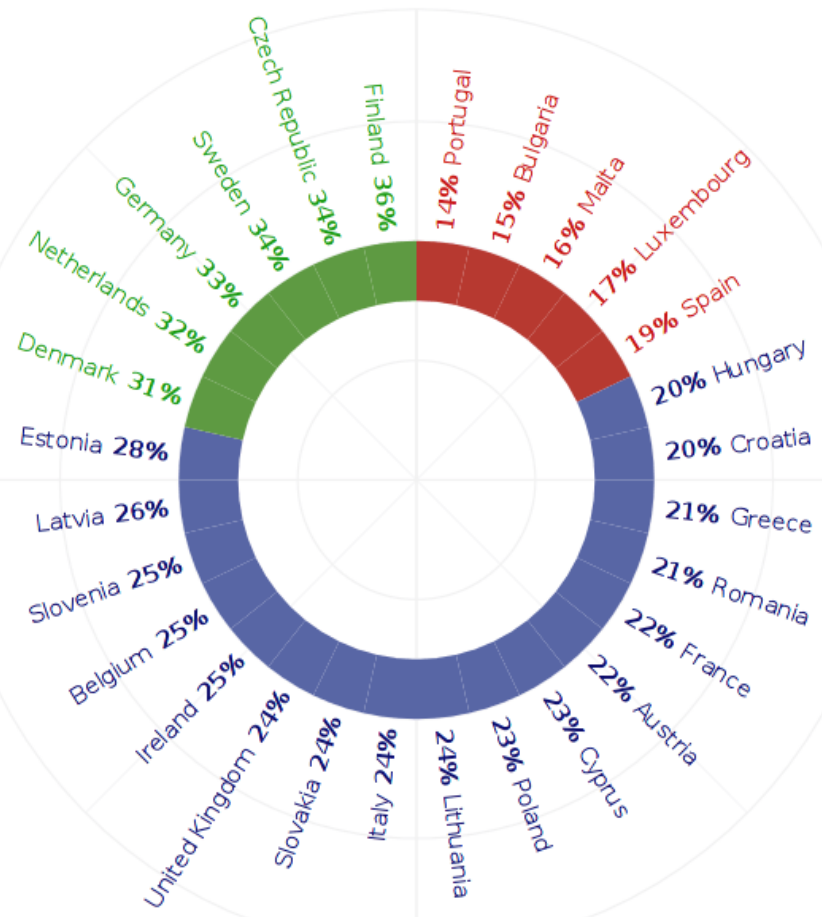

Figure no. 2. The share of respondents that declared they used IT devices between $1 / 4$ and $3 / 4$ of the time, by country, \%

Source: Eurofound, 2015.

According to the results of the Sixth European Working Conditions Survey, Romania was placed on a higher position than the EU-average in terms of public administration, education and health $(40 \%$ of the Romanian workers from these sectors have declared they used IT devices between $1 / 4$ and $3 / 4$ of the working time, as compared to $37 \%$ - EU average). A similar situation was recorded as regards the sector of construction and transport: Romania $-23 \%$ vs. EU average $-20 \%$. In 


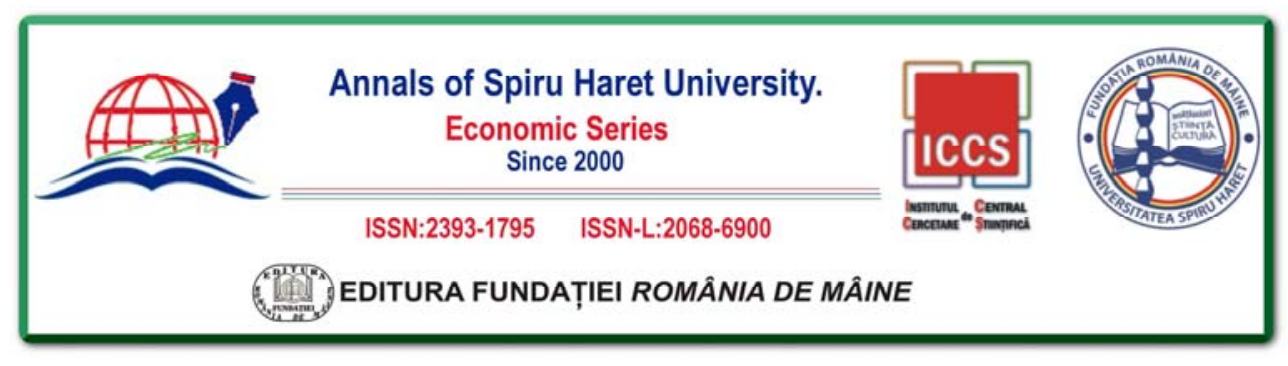

Issue $2 / 2018$

turn, Romania ranked on inferior positions from the point of view of the share of those answering that they (almost) never used IT devices at work. The greatest discrepancies were recorded in financial and other services (55\% vs. $34 \%-\mathrm{EU}$ average) and in agriculture and industry (55\% vs. $75 \%$ - EU average). As regards to the share of answers indicating the use of IT devices at work (almost) all of the time, commerce and hospitality represents the only sector for which Romania recorded a highest share compared with the EU average (30\% vs. $25 \%$ ).

The analysis of the answers received irrespective of workers' sector of activity revealed that Romania ranked in the group of EU states with the lowest shares of respondents that indicated they worked with IT devices (almost) all of the time (21\%, representing the second lowest share within the EU; by comparison, Luxembourg accounted for the highest share: $52 \%$ ).

At the same time, Romania was placed between Greece (21\%) and France $(22 \%)$, the share indicating that the persons worked with IT devices between $1 / 4$ and $3 / 4$ of the time ( $21 \%$ vs. $36 \%$ in Finland, representing the highest share).

The results of the latest survey also indicate that about $9 \%$ of the employees in the EU member states use IT devices outside of the employer's premises. The share of employees that telework mainly from home was $2 \%$. The share of ICT-mobile workers was 7\%, namely those who used IT devices at least three quarters of all time outside of the employer's premises [Eurofound, 2017].

In Europe, in 2013, unemployment was high and also there were unfilled vacancies in ICT (according to Neelie Kroes, Vice-President of the European Commission responsible for the Digital Agenda at that time), underlying the need to take actions in favour of digitally skilled workers. The proposals in this respect were related to: raising awareness related to ICT careers; modernising education, mainstreaming ICT for pupils; matching ICT training offer with the labour market needs; encouraging mobility for ICT workers; creating a system for recognising qualifications in ICT by employers, in various European countries [European Commission, 2013].

An important objective in the EU aimed at supporting connectivity of web entrepreneurs, creating awareness about ICT importance for entrepreneurship activities. Also, another EU objective was related to the support of young women and their interest in ICT careers, as they are under-represented in the industry [European Commission, 2013b].

Within the EU, there was a key performance target for halve the number of Internet non-users from $30 \%$ (in 2009) to $15 \%$ by 2015 . In 2012 the rate fell to 


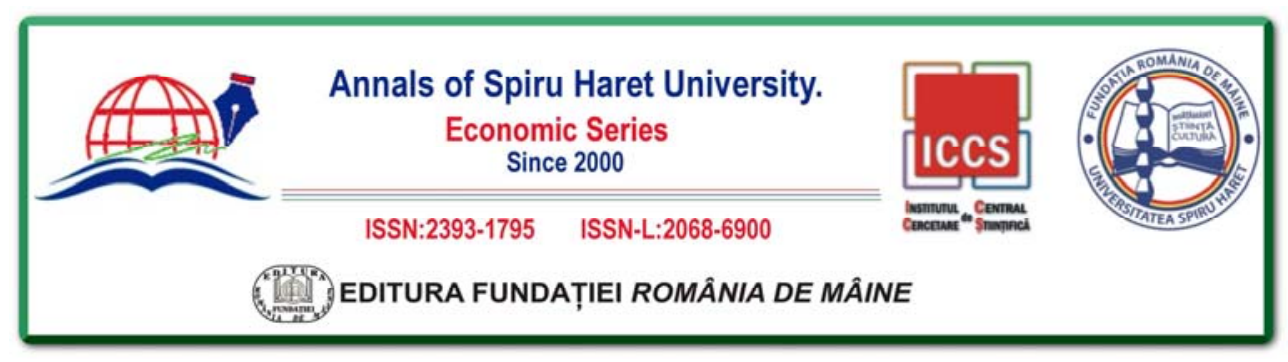

\section{Issue $2 / 2018$}

$22 \%$, this rate varying substantially by country: in Sweden was about $5 \%$, while a rate of about $40 \%$ was found in Bulgaria, Greece, and Romania. The reducing rates of non-use had the following profile: Portugal (-7 p.p., to 34\%), the Czech Republic (-5 p.p, to $19 \%$ ), Cyprus (-5 p.p., to $36 \%$ ), Croatia (-4 p.p., to $35 \%$ ), Lithuania (-3 p.p., to $30 \%$ ), Italy (-2 p.p., to $37 \%$ ), Poland (-1 p.p., to $32 \%)$, etc. [European Commission, 2013c].

More recently, the studies related to teleworking are focused on a variety of topics, such as:

- the effects of telework and flexible work schedules on the performance of teams in new product development (NPD) projects; telework has a positive effect on NPD performance [Coenen and Kok, 2014];

- the gap between high social expectations and the reality of home-based telework; telework it is mainly an informal working arrangement [Aguilera et al, 2016];

- the implementation of telework, highlighting the inconsistencies in the outcomes of various surveys, discrepancies resulted from differences in legislation of countries and methodologies used in surveys [Bajzikova et al, 2016];

- the organisational measures for enhancing individual and organizational outcomes of telework [Bentley et al, 2016];

- the comparison and identification of the differences between traditional work arrangements and telework; a leadership model for teleworkers' induction is presented [Wojcak et al, 2016];

- how organizational structures shape communication flows of membership negotiation and activity coordination (flexibility policies related to worker teleworking) [Nordback et al, 2017];

- the use of information and communication technology (ICT) by older people; a great number of older people working with ICT agree to work longer if they can use telework [Arvola et al, 2017a];

- the interaction between senior employees' teleworking and well-being [Arvola et al, 2017b];

- the analysis of the effects of telework and ICT-mobile work on the world of work; the incidence of this type of work arrangement varies substantially across countries [Messenger, 2017];

- the critical elements for telework programs' sustainability in a multinational company [Aderaldo et al, 2017]; 


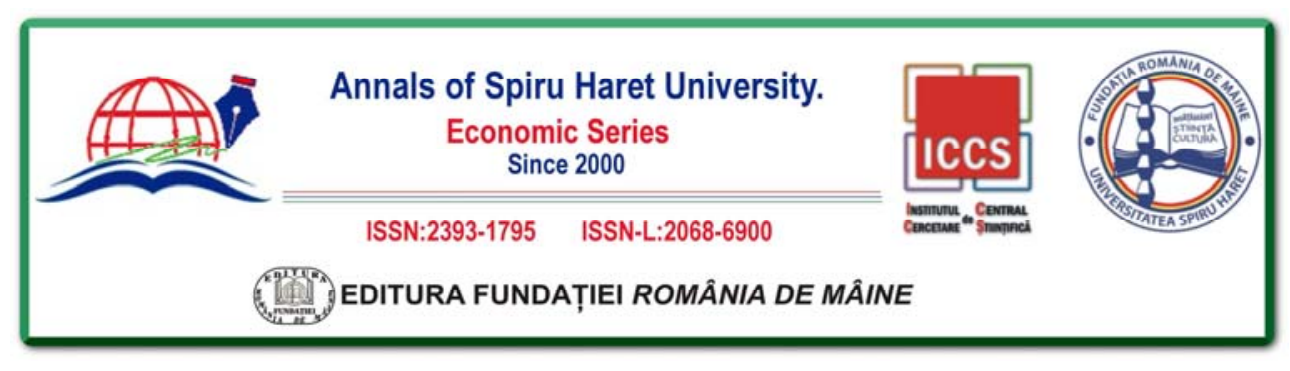

Issue $2 / 2018$

- the modelling concept to simulate the decision to telework [Moeckel, 2017];

- the main features of changes in desire for mobility and the opportunities and tools available to meet them (changes occurred as a result of ICT) [Snellen \& de Hollander, 2017];

- the features that characterize telework; telework is likely to yield more good than bad for individual health [Tavares, 2017];

- the relationship between teleworking, air quality and traffic; teleworking can be a tool for urban planning and development [Giovanis, 2018].

E-work has a number of limitations, as well as advantages. The perception of human resources experts is different and it takes into account various aspects, such as: the content of the work, work place, the activities with business partners and characteristics derived from e-work activity, but also aspects related to eemployment (particularities related to gender, age, area of activity, etc.).

In order to observe e-work trends, factors influencing individuals behaviour (e.g., gender, age, level of training) are important, but also the work place characteristics, such as type of the activity of the company, endowment with ICT equipment, substitution of "face-to-face" communication with online communication, etc. Also, the location where the worker activity is performed is important, that can be at the office, at worker' home (location is fixed), mixed, or unspecified (using smartphones, tablets, laptops, etc.).

\section{E-work assessment}

E-work might provide various advantages, both for employees and employers. Teleworking activities might allow a balance between activity at workplace and family life, providing to the employees a sense of flexibility.

Through e-work is possible to develop various job tasks right from home and this is achievable due to technological progress. Also, this is possible due to the new skills that individuals have, mainly related to use of computers, electronic devices, computer software, and so on.

For employees and employers, the assessment of e-work may take into consideration the following aspects:

- the accessibility to employment, expanding the categories of persons who can perform such activities - with the advantage of the possibility to work from home for people with disabilities; also, there is the situation of the improvement of the 


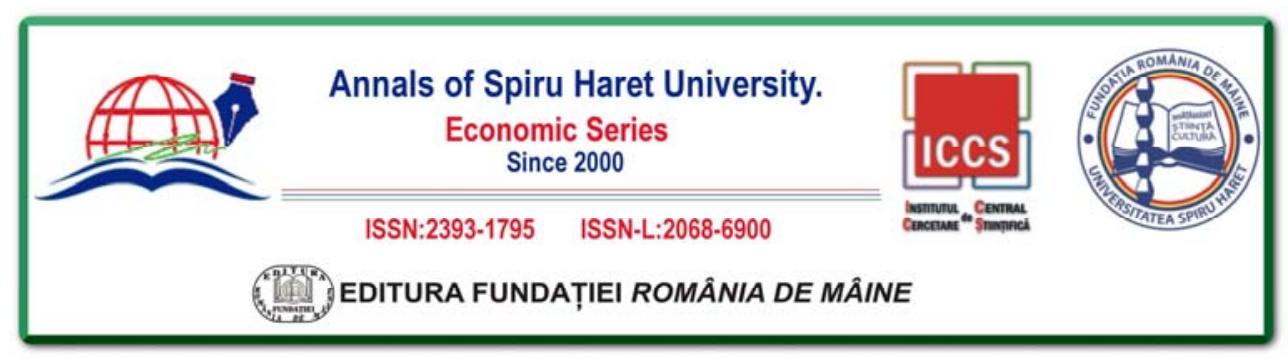

\section{Issue 2/2018}

work-life balance. The disadvantage is related to difficulties that may arise in the situation of solving job tasks, if the employee has children and they are at home. Another disadvantage of the employee working from home is the lack of interaction with peers, which can lead to a state of discouragement and loneliness. Also, there might be a higher involvement in child care and a low involvement in solving job tasks. The opportunities are related to the reduction in rush hour traffic jams, reduction of number of accidents, reduction of the pressure on infrastructure, and reduction of greenhouse gas (GHG) emissions and energy consumption;

- in the area of knowledge and skills, there may be some disadvantages related to the minimum standards and qualifications needed for e-work;

- individual performance at job (productivity and work quality), with the advantage of the reduction of the time spent in the means of transportation, which can be used to work on tasks, but also with disadvantages related to the idea that the employee may be easily attracted by other activities and may neglect the job tasks. Some risks might appear, such as unannounced interruptions in electricity supply at home, which can lead to loss of data. There are opportunities related to the fact that the worker will not be bothered by other co-workers;

- teambuilding is important in a company, but for an employee working from home, there is the disadvantage of low possibility to socialize with peers;

- flexibility in the workplace provides the advantage to the worker to create his own working program. The disadvantages might be related to the overtime work, resulting in extension of work time. The risks may be related to fatigue, stress, and illness, while the opportunities are connected to the possibility for the worker to solve other tasks not related to the job;

- autonomy - the employee may have the possibility to work on its own, with many breaks, as long as at the end of the day the deliverables are sent to the employer. The disadvantages may be expressed by frequently phone calls received from business premises with new tasks to be solved, a permanent link (24 h) with the employer being thus created;

- risks related to career evolution - solutions to various problems can easily be found in the meetings from the work place;

- working conditions, with the advantage for the employee of the increase employment flexibility; some risks may be related to the necessity to protect the data used and processed by teleworker for business purposes; the employer has to respect the privacy of the teleworker; 


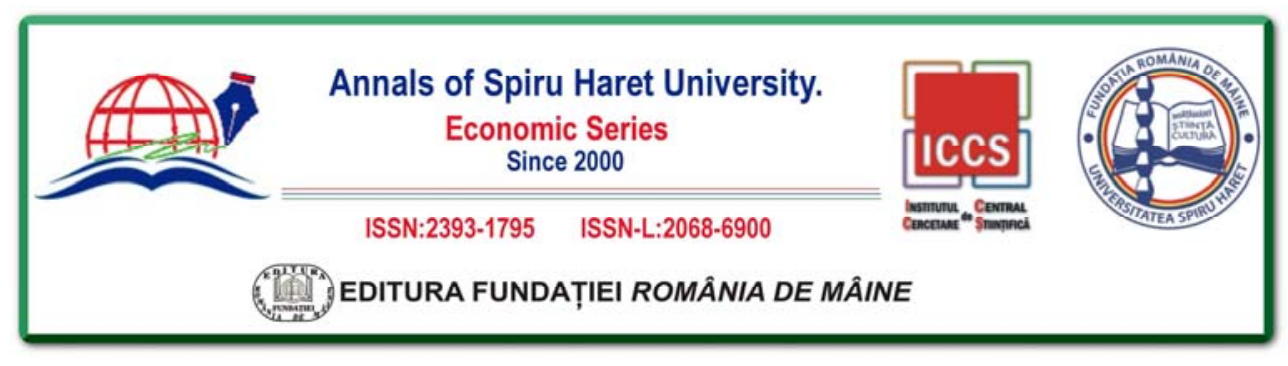

Issue $2 / 2018$

- expenses related to the job, with the advantage of reduced transport costs for the worker; advantages for employers may be expressed through: decreasing maintenance costs with company offices, decreasing labour costs for e-workers, decreasing parking fees level for employees' cars. The disadvantage may be related to an increase of the equipment costs (where a PC and an Internet subscription are made available to employee to work from home); for employees, a risk may appear, related to the unequal treatment of workers (from the office) and remote workers;

- for the employer, another disadvantage may arise if the tasks solving process by the employee cannot be monitored.

\section{Box no. 1. The impact of telecommuting/teleworking on the new employment model, underlined by various surveys}

In 2015, in the U.S.A., telecommuting represented an option that is rather linked to a particular socioeconomic status and educational attainment, being adopted more frequently by the most educated workers $(55 \%$ of college graduates declared that they telecommuted, as compared with $26 \%$ of non-college graduates), those who earn higher incomes $(52 \%$ of those having an annual household income of $\$ 75,000$ or more, as against $26 \%$ of those earning below $\$ 75,000)$ and white-collar professionals (44\% declared they telecommuted, as compared with $16 \%$ of bluecollar professionals). The share of workers that telecommuted has increased four times, from $9 \%$ in 1995 to $37 \%$ in 2015 . The perceived productivity of those who worked remotely was about similar to that of employees working in offices for $56 \%$ of telecommuting respondents, while $24 \%$ of them considered that the first category was made up of more productive workers (Gallup's Work and Education poll was conducted between 5 and 9 August 2015 on a sample of 1011 adults, aged 18 and older) [Jones, 2015].

The survey carried on in 2015 (February-May) on an international sample of 2,759 knowledge workers revealed that almost $80 \%$ of the respondents performed telework. Near two thirds of this category declared that they have noticed a positive change in the attitude towards telework within their organizations. Also, $60 \%$ of teleworking respondents declared that they would quit their current job for a similar position with the same pay if they could work from home full time. More than half of the $20 \%$ of respondents that never performed their job tasks outside the 


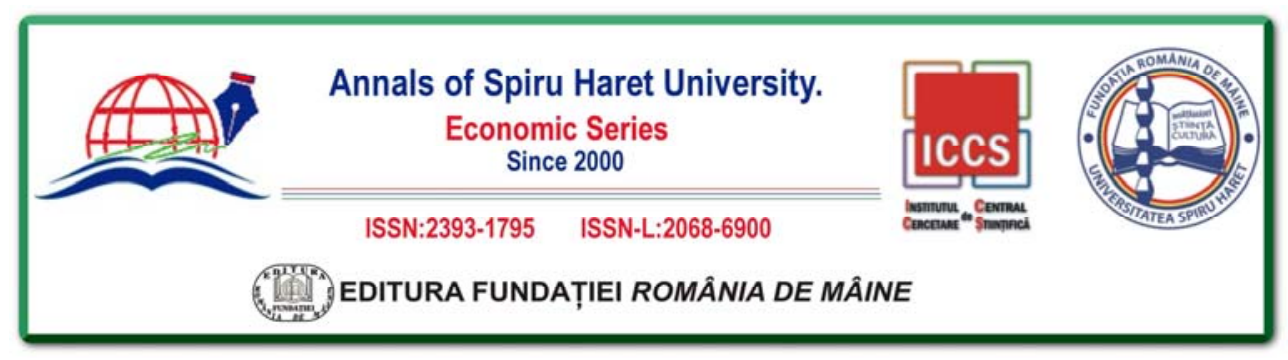

Issue 2/2018

company offices mentioned that they wished they could telework [PGi Global Telework Survey, 2015].

A more recent survey conducted in 2016 on knowledge workers from all over the world highlighted that the majority of respondents were working from home only one day per week or less. The highest share of this category was found in Asia Pacific region (68\%), followed by North America (58\%) and Europe and Middle East region (51\%). However, as compared to the results of 2015 survey, teleworkers expressed their desire to work more days outside the company offices. Thus, $52 \%$ of the teleworking respondents of Asia Pacific region and half of the North American ones mentioned that they were willing to work from home more often if they could, the ideal frequency being 2 or 3 days per week [PGi Global Telework, 2016].

In the U.S.A., employees have more than twice options to work remotely when hired by large companies (with over 500 workers), as compared to small ones (with less than 100 employees). At the same time, the chances for a full-time worker to be allowed to work remotely are four times higher than for a part-time worker [Global World Analytics, FlexJobs, 2017]. The demand for remote workers is on the rise, as indicated by the high share of professionals $(81 \%)$ that evaluated the option to telecommute as being more important to them than having a flexible working time or working part-time [Weiler Reynolds, 2018a].

Jobs that involve remote work have become increasingly prevalent on the labour market, mainly because of the technological advance and mobile devices development. Such type of employment is sought by workers because it may provide a greater work-life balance.

\section{Box no. 2. Companies with an important focus on providing remote jobs}

There are various companies that offer some work-at-home opportunities, using a remote workforce, and thus are telecommute-friendly companies. For example, there are companies such as [Miles Brunelli, 2017]:

- Aetna (insurance and managed care company), with telecommuting position types: nurses, physicians, network managers, claims adjusters;

- American Express, with telecommuting position types: travel counsellor (call centre), sales, corporate; 


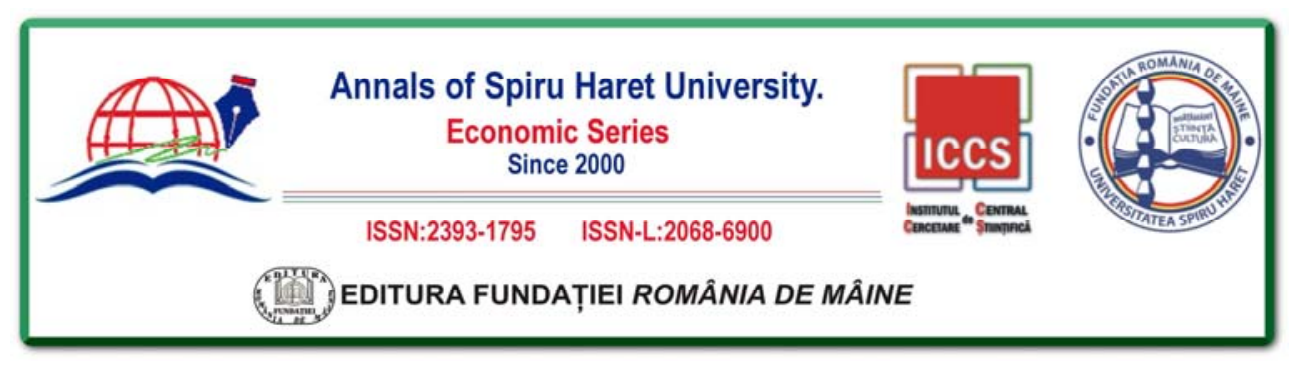

Issue $2 / 2018$

- Cigna (insurance, managed care), with more than 3,000 workers telecommuting, and with telecommuting position types: nurses, case managers, claims workers, analysts;

- Deloitte (consulting), offering most of its 45,000 employees the option to telecommute as many as five days a week;

- McKesson (healthcare services), with a telecommuting workforce of nurses, where 800 of them are working in call centres performing telephone triage and disease management; in this division of the company between $80-85 \%$ of its workers are full-time telecommuters; the telecommuting position types are: nurses, physicians and marketing, IT and sales professionals.

According to remote.co, there are companies providing remote jobs, such as:

- Dell, $18 \%$ remote, with a team above 140,000 members, and with headquarters in Texas, U.S.A.;

- VIPKID (provides for teachers from the U.S.A. and Canada the opportunity to teach Chinese kids ages 5-12 online), 85\% remote, with a team above 16,500 members, and with headquarters in Beijing, China;

- Canonical (software development company), 75\% remote, with a team above 700 members, and headquarters in London, U.K.;

- Automattic Inc. (web development company), 100\% remote, with a team above 600 members, and headquarters in San Francisco, U.S.A.;

- Answer Connect (providing help to small and medium businesses), 100\% remote, with a team above 500 members, and headquarters in Portland, U.S.A.;

- Appirio, a Wipro Company (helps create worker \& customer experiences using the latest cloud technologies), $100 \%$ remote, with a team above 500 members, and headquarters in Indianapolis, U.S.A.;

- Toptal (provides software solutions for businesses), 100\% remote, with a team above 400 members, and no headquarters;

- Qkids (e-learning, K-12 English education company), 50\% remote, with a team above 300 members, and with headquarters in Xiamen, China;

- Envato (applications development), 100\% remote, with a team above 80 members, and headquarters in Melbourne, Australia;

- FlexJobs (job service for telecommuting and other flexible job listings), $100 \%$ remote, with a team above 70 members, and no headquarters; 


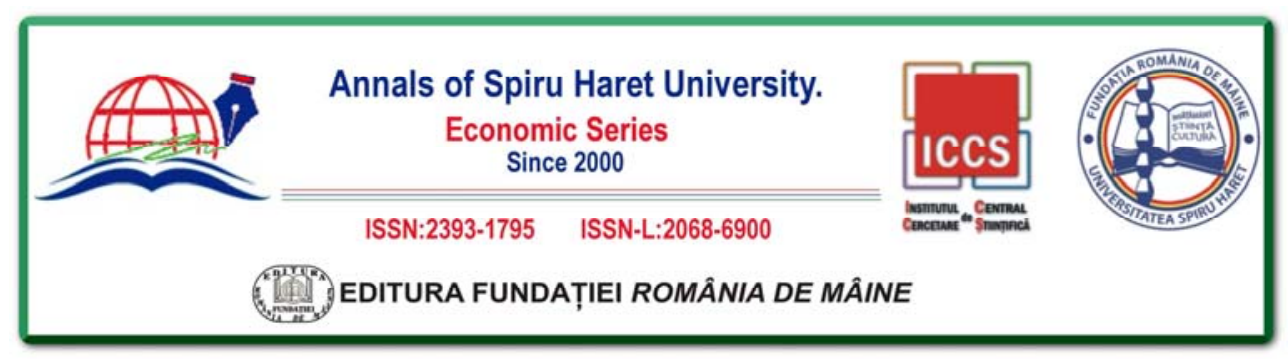

Issue $2 / 2018$

- Worldwide101 (provides virtual assistants for businesses), $100 \%$ remote, with a team above 70 members, and with headquarters in U.K.;

- DVMelite (business development for veterinary offices), 100\% remote, with a team above 50 members, and headquarters in Halifax, Canada;

- Toggl (provides online time tracking tool for various projects), $50 \%$ remote, with a team above 40 members, and with headquarters in Tallinn, Estonia;

- Ushahidi (open source software development), $60 \%$ remote, with a team above 30 members, and with headquarters in Nairobi, Kenya;

- DevriX (provides technical and business solutions), 90\% remote, with a team above 25 members, and headquarters in Sofia, Bulgaria;

- Eyeo $\mathrm{GmbH}$ (software development), $100 \%$ remote, with a team above 20 members, and headquarters in Köln, Germany.

The analysis of the first 100 companies operating in the U.S.A. that listed the most remote jobs in 2018 reveals top career fields for that the respective companies are seeking remote workers, with some examples of companies [Weiler Reynolds, 2018b]:

1) medical and health: UnitedHealth Group, Anthem, Inc., Humana;

2) computer and IT: Dell, Xerox, Teradata;

3) education and training: VIPKID, Kaplan, Western Governors University;

4) sales: HD Supply, NCH Corporation, Williams-Sonoma;

5) customer service: SYKES, Working Solutions, Amazon;

6) accounting and finance: JLL - Jones Lang LaSalle, Wells Fargo, JPMorgan Chase;

7) travel and hospitality: Hilton, BCD Travel, Carlson Wagonlit Travel.

In a similar ranking developed a year before (2017), the seventh place in the ranking of the most wanted career fields for remote workers was held by Government (U.S. Department of Agriculture, U.S. Department of State, U.S. Department of Commerce) [Weiler Reynolds, 2017].

Among the career fields that recorded the highest increases in numbers of listings for remote workers are therapy, virtual administration, client services, tutoring, and state and local government. At the same time, the 20 most common job titles based on working remotely include teacher, developer, analyst, sales representative, nurse, accountant, and program manager [Weiler Reynolds, 2018b]. 


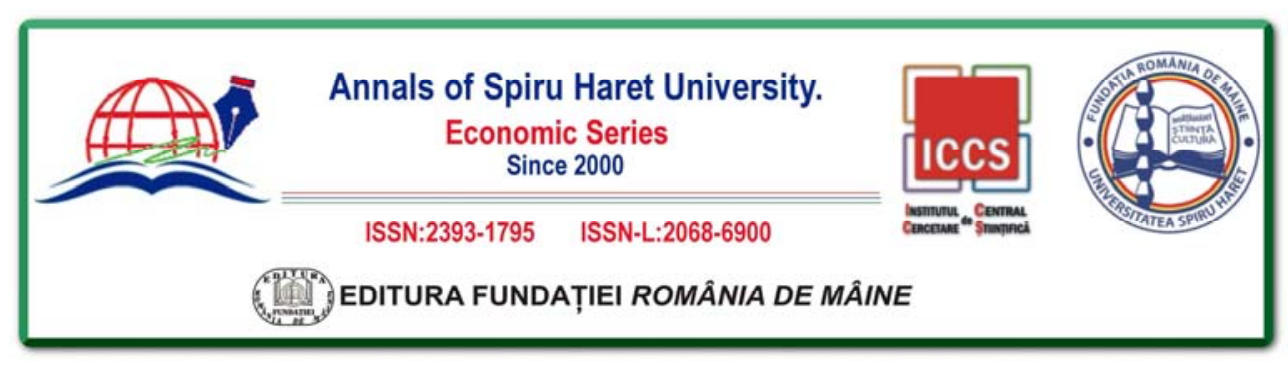

Issue $2 / 2018$

There are various companies who have adopted e-work. It seems to help keeping the environment cleaner by reducing GHG emissions, increasing the degree of personal freedom and flexibility, and reducing stress at work. Companies can make significant savings in terms of cost of renting office space, operating costs, etc.

\section{Final remarks}

A combination of work from home with work from office is one of the solutions of adopting e-work by many companies in various sectors. There are economic activities not suitable for e-work. Also, there are various approaches of e-work, referring to people who practice telework as self-employed, telesellers, persons who conduct a business, mobile workers, etc. An essential aspect is that these workers use ICT to perform job tasks.

E-work may be supported by aspects such as:

- ICT facilities development (many activities are completed online communication, transmission of decisions, relationship with partners);

- the analysis of the profile of young graduates - underline that they are more familiar with ICT and they prefer ICT to traditional forms of performing job tasks;

- business environment analysis - current businesses grow by orders, projects, which increase the share of persons temporary or part time employed.

E-work is a present and future opportunity for job creation, is an emerging process, and supports the development of a new business model. Individuals having knowledge of ICT have also chances to get high-paid jobs on labour market. Thus, the education system plays an important role in guiding and preparing young people in terms of acquiring necessary knowledge for becoming specialists in various fields. A future research may take into consideration the analysis of the relationship between ICT adoption and the employment level, using various econometric techniques.

\section{References}

1. Aderaldo, I.L., Aderaldo, C.V.L., Lima, A.C., "Critical Aspects of Telework in a Multinational Company," Cad. EBAPE.BR, v. 15, Special Edition, Article 8, Rio de Janeiro, Sept. 2017.

2. Aguilera, A., Lethiais, V., Rallet, A., Proulhac, L., "Home-based Telework in France: Characteristics, Barriers and Perspectives," Transportation Research Part A 92 (2016): $1-11$. 


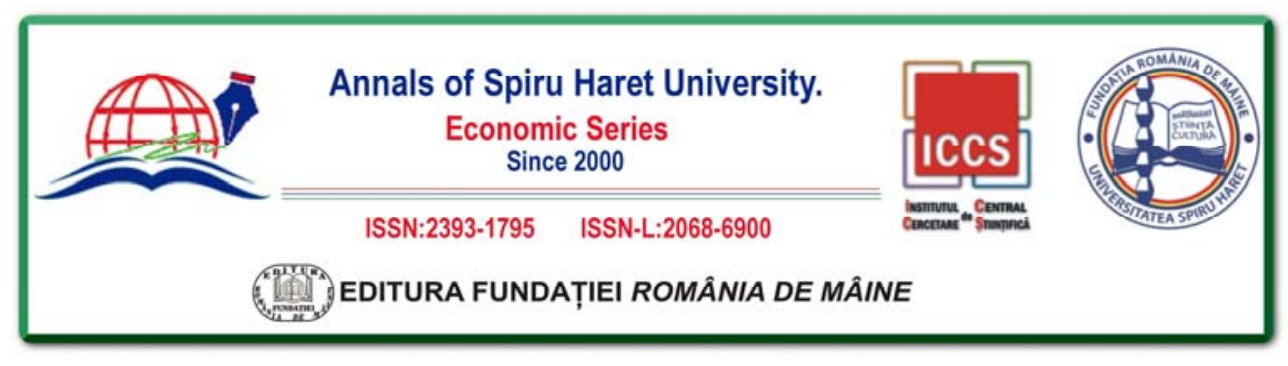

\section{Issue $2 / 2018$}

3. Arsov, B., Telework in Bulgaria, 2008, http://www.eurofound.europa.eu/eiro/2007/11/ articles/bg0711049i.htm.

4. Arvola, R., Lutsoja, K., Kristjuhan, Ü., Tint, P., "Telework as an Option to Postpone the Retirement for Ageing People?," Safety of Technogenic Environment, 8 (2017a): 15-23.

5. Arvola, R., Tint, P., Kristjuhan, Ü., Siirak, V., "Impact of Telework on the Perceived Work Environment of Older Workers," Scientific Annals of Economics and Business, 64 (2), (2017b): 199-214.

6. Bajzikova, L., Sajgalikova, H., Wojcak, E, Polakova, M., "How Far is Contract and Employee Telework Implemented in SMEs and Large Enterprises? (Case of Slovakia)," Procedia - Social and Behavioral Sciences 235 (2016): 420 - 426.

7. Bates, P., Huws, U., Modelling E-work in Europe, Estimates, Models and Forecasts from the Emergence Project, 2002, IES Report 388.

8. Bălan, M., "Youth Employment on the Romanian Labour Market in the Context of the Current Economic and Financial Crisis," Annals of Spiru Haret University. Economic Series, Vol. 11, No. 1, 2011.

9. Bentley, T.A., Teo, S.T.T., McLeod, L., Tan, F., Bosua, R., Gloet M., "The Role of Organisational Support in Teleworker Wellbeing: A Sociotechnical Systems Approach," Applied Ergonomics 52, (2016): 207-215.

10. Bigley, N., "Teleworking: Is It Right for Your Organization?," Franchising World 37. 8, (2005): 33-35.

11. Ciutacu, C., Telework in Romania, 2008, Eironline, http://www.eurofound.europa.eu/ eiro/2007/12/articles/ro0712019i.htm.

12. Coenen, M., Kok, R.A.W., "Workplace Flexibility and New Product Development Performance: The Role of Telework and Flexible Work Schedules," European Management Journal, 32, (2014): 564-576.

13. Coletto, D., Telework in Italy, 2008, Eironline, http://www.eurofound.europa.eu/eiro/ 2007/12/articles/it0712049i.htm.

14. Díaz, J.A., Telework in Spain, 2008, Eironline, http://www.eurofound.europa.eu/eiro/ 2008/02/articles/es0802059i.htm.

15. European Commission, Commission Staff Working Paper - Report on the implementation of the European social partners' Framework Agreement on Telework, Brussels, 2008.

16. European Commission, Reconciliation between Work, Private and Family Life in the European Union, Eurostat Statistical Books, 2009.

17. European Commission, SPEECH: The digital economy delivers jobs: FACT, European Commission - SPEECH/13/181, 04/03/2013, Neelie Kroes, Vice-President of the European Commission responsible for the Digital Agenda, The Grand Coalition for ICT 


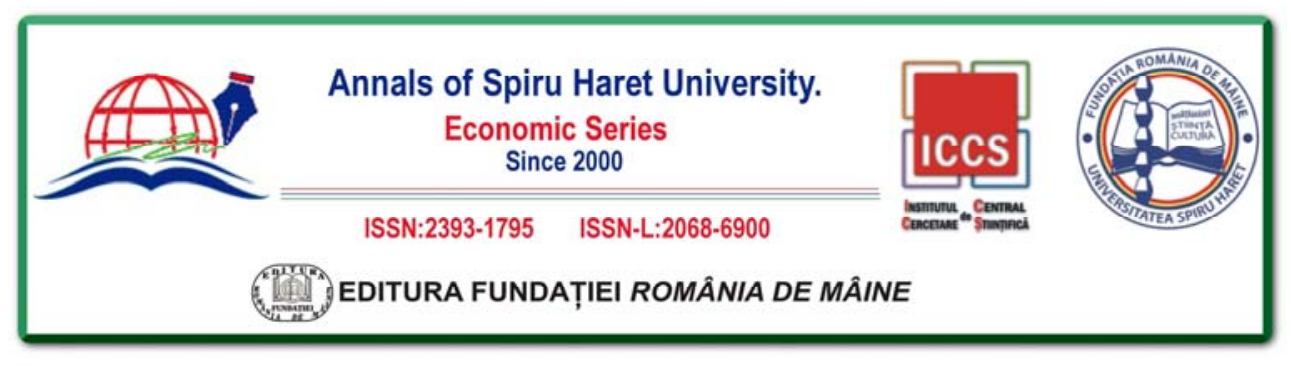

Issue $2 / 2018$

skills and jobs conference/Brussels, 4 March 2013, http://europa.eu/rapid/pressrelease_SPEECH-13-181_en.htm.

18. European Commission, Digital Jobs, Creating the Right Conditions for Europe's Entrepreneurs to Launch and Grow Sustainable Business, 2013b, http://ec.europa.eu/ digital-agenda/en/digital-jobs-0.

19. European Commission, Digital Agenda Scoreboard 2013, Commission Staff Working Document, Brussels, 12.06.2013, SWD(2013) 217 final, 2013c, http://ec.europa.eu/ digital-agenda/sites/digital-agenda/files/DAE\%20SCOREBOARD\%202013\%20\%20SWD\%202013\%20217\%20FINAL.pdf.

20. Eurofound, European Working Conditions Survey, Office for Official Publications of the European Communities, 2005.

21. Eurofound, Fifth European Working Conditions Survey: Overview Report, Luxembourg, Publications Office of the European Union, 2012.

22. Eurofound, European Working Conditions Survey (EWCS), https://www.eurofound. europa.eu/data/european-working-conditions-survey, 2015.

23. Eurofound, Sixth European Working Conditions Survey - Overview report (2017 update), Publications Office of the European Union, Luxembourg.

24. Flecker, J., Kirschenhofer, S., Jobs on the Move, European Case Studies in Relocating E-work, IES Report 386, 2002.

25. Giovanis, E., "The Relationship between Teleworking, Traffic and Air Pollution," Atmospheric Pollution Research, 9, (2018): 1-14.

26. Global World Analytics, FlexJobs, State of Telecommuting in the U.S. Employee Workforce, https://cdn.thepennyhoarder.com/wp-content/uploads/2017/06/30140000/ State_Of_Telecommuting_U.S._Employee_Workforce.pdf), 2017.

27. Hárs, Á., Neumann, L., Telework in Hungary, 2008, http://www.eurofound.europa.eu/ eiro/2008/01/articles/hu0801069i.htm.

28. ILO, Challenges and opportunities of teleworking for workers and employers in the ICTS and financial services sectors: Issues paper for the Global Dialogue Forum on the Challenges and Opportunities of Teleworking for Workers and Employers in the ICTS and Financial Services Sectors, Geneva, 24-26 October 2016, International Labour Office, Sectoral Policies Department, Geneva, http://www.ilo.org/wcmsp5/ groups/public/---ed_dialogue/---sector/documents/publication/wcms_531111.pdf.

29. INS, Ancheta fortei de munca in gospodarii (AMIGO), 2014.

30. Jean, S., Labour Code covers teleworking, Eironline, http://www.eurofound.europa.eu/ eiro/2012/04/articles/fr1204011i.htm, 21-06-2012.

31. Jones, J.M., In U.S., Telecommuting for Work Climbs to 37\%, http://news.gallup.com/ poll/184649/telecommuting-work-climbs.aspx, 2015. 


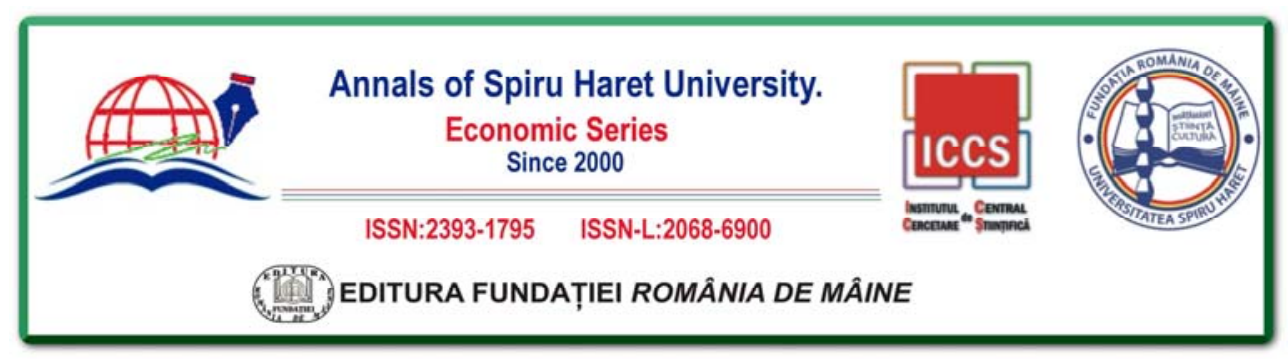

\section{Issue $2 / 2018$}

32. Messenger, J.C., "Working Anytime, Anywhere: The Evolution of Telework and its Effects on the World of Work," IUSLabor 3/2017, 301-312.

33. Messer, R., "Going Nowhere - But Fast! E-Employment - The Next Internet Revolution,” Business Information Review, 27(2), (2010): 101-103.

34. Miles Brunelli, L., Top 10 Telecommuting Companies. See Why These 10 Major Corporations Are Truly Telecommuter Friendly, https://www.thebalancecareers.com/ top-telecommuting-companies-3542783, 2017.

35. Moeckel, R., "Working from Home: Modeling the Impact of Telework on Transportation and Land Use," Transportation Research Procedia, 26, (2017): 207-214.

36. Nordback, E.S., Myers, K.K., McPhee, R.D., "Workplace Flexibility and Communication Flows: A Structurational View," Journal of Applied Communication Research, 45(4), (2017): 397-412.

37. OECD. Broadband and the economy, Ministerial Background Report, DSTI/ICCP/ IE(2007)3/Final, 2008.

38. Perez, P.M., Carnicer, M.P.L., Sanchez, A.M., "Differential Effects of Gender on Perceptions of Teleworking by Human Resources Managers," Women in Management Review, 17, 5/6, (2002): 262-275.

39. Perez, M.P., Sanchez, A.M., Carnicer, M.P.L., "The Organizational Implications of Human Resources Managers' Perception of Teleworking," Personnel Review, 32, 6, (2003): 733-755.

40. Perez, P.M., Sanchez, A.M., Carnicer, M.P.L., Jimenez, V., Jose, M., "The Environmental Impacts of Teleworking: A Model of Urban Analysis and a Case Study," Management of Environmental Quality, 15, 6, (2004): 656-671.

41.Perez, P.M., Sanchez, A.M., Carnicer, M.P.L., Jimenez, V., Jose, M., "A Technology Acceptance Model of Innovation Adoption: The Case of Teleworking," European Journal of Innovation Management, 7, 4, (2004b): 280-291.

42. Perez, P.M., Sanchez, A.M., Carnicer, M.P.L., Jimenez, V., Jiménez, M.J.V., "The Synergism of Teleworking and Information and Communication Technologies," Journal of Enterprise Information Management, 18, 1/2, (2005): 95-112.

43. PGi Global Telework Survey, Trends around the World Shaping the Future of Work, http://go.pgi.com/gen-genspec-15telesur-SC1129, https://img03.en25.com/Web/ PremiereGlobalServices/\%7B7e70c99d-24b4-43c3-96f9-4c3a24698cf4\%7D_2015_ PGi_Global_Telework_Survey.pdf, 2015.

44. PGi Global Telework, 2016 Survey Results, https://img03.en25.com/Web/Premiere GlobalServices/\%7B28aa453d-300f-4292-ab54-7e925397de79\%7D_2016_Global_ Telework_Survey.pdf, 2016.

45. Snellen, D., de Hollander G., "ICT'S Change Transport and Mobility: Mind the Policy Gap!," Transportation Research Procedia, 26, (2017): 3-12. 


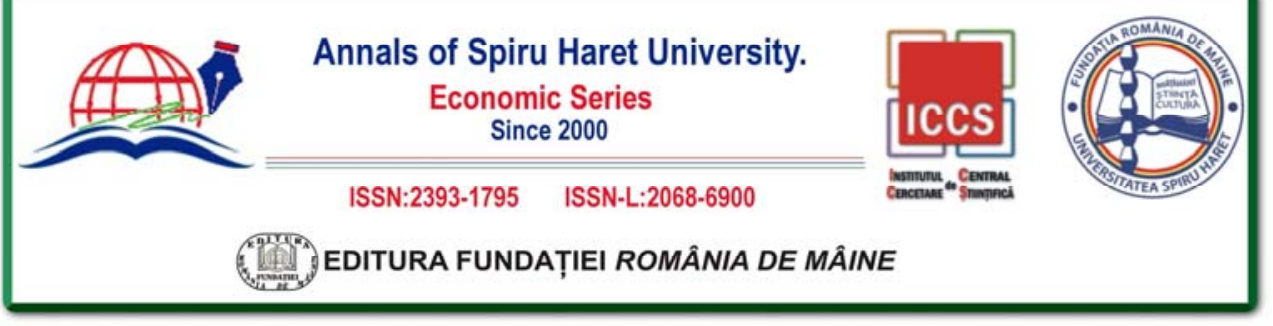

Issue $2 / 2018$

46. Tavares, A.I., "Telework and Health Effects Review," International Journal of Healthcare 2017, Vol. 3, No. 2.

47. Weiler Reynolds, B., 100 Top Companies with Remote Jobs in 2017, 2017, https://www.flexjobs.com/blog/post/100-top-companies-with-work-from-home-jobs-in$2017 /$.

48. Weiler Reynolds, B., Infographic: Finding a Remote Job and 100 Companies Hiring, 2018a, https://www.flexjobs.com/blog/post/infographic-finding-a-remote-job-100companies-hiring/.

49. Weiler Reynolds, B., 100 Top Companies with Remote Jobs in 2018, 2018b, https://www.flexjobs.com/blog/post/100-top-companies-with-remote-jobs-in-2018/.

50. Welz, C., Wolf, F., Telework in the European Union, Eurofound, 2010, http://www.eurofound.europa.eu/eiro/studies/tn0910050s/tn0910050s 1.htm.

51. Wojcak, E., Bajzikova, L., Sajgalikova, H., Polakova, M., "How to Achieve Sustainable Efficiency with Teleworkers: Leadership Model in Telework," Procedia - Social and Behavioral Sciences, 229, (2016): 33-41.

52. www.remote.co, a resource for companies with remote jobs. 
